The Geneva Papers on Risk and Insurance, 22 (No. 82, January 1997) 26-37

\title{
Reinventing Reinsurance Using the Capital Markets
}

\author{
by Richard E. Smith*, Emily A. Canelo** and Anthony M. Di Dio***
}

\section{Introduction}

Few people realize that in 1792 the New York Stock Exchange was established in lower New York City to service the financial investment needs of the insurance industry. ${ }^{1}$ In time however, the wealth generated by Wall Street far surpassed that of the insurance industry. Regrettably, until only recently the insurance industry lost sight of the fact that insurance risks can support the creation of financial capital in a global economy.

Not surprisingly the wake up call for the insurance industry came from a string of natural catastrophes occurring over the last six years, whose costs dwarfed those previously incurred by insurers. In fact, as the accompanying graphs at the end of this article illustrate, the number of property catastrophes has fallen since the late 1970 s from about 230 to 160 , but the average industry insured loss per catastrophe has soared since 1980 from $\$ 28$ million to $\$ 250$ million. Consequently, the total insured catastrophe losses from hurricanes, earthquakes and other natural perils for the five year period ending 1995 have amounted to a staggering $\$ 4$ billion, compared to $\$ 11$ billion over the previous five year period. ${ }^{2}$ Moreover, predictions about the rising costs of property catastrophe losses are being given greater credibility primarily because of (i) the rising values of insured risks; (ii) higher population densities in catastrophe prone areas; and most importantly (iii) the new and sophisticated catastrophe loss modelling techniques, which vary somewhat in approach, but provide insurers and reinsurers with better estimates of the amount of the insured property loss they might sustain arising out of a specific catastrophic event. ${ }^{3}$

"President and Chief Executive Officer. Zurich Reinsurance Centre. Inc.

** Senior Vice President. Underwriting/Contracts Manager. Zurich Reinsurance Centre. Inc.

**** Senior Vice President. Underwriting/Property Manager. Zurich Reinsurance Centre. Inc.

${ }^{1}$ See generally. R.C. Michie. "Development of Stock Markets". In The New Palgrave Dictionary of Money and Finance, Vol. 1. Ed. Peter Newman et al.. New York. Stockton Press. 1992. pp. 662-668.

${ }^{2}$ Data supplied by Property Claim Services of Rahway. New Jersey and adjusted for inflation using the consumer price index.

${ }^{3}$ Sean Mooney, "The Life and Death of Probable Maximum Loss". National Underwriter. 30 Sept. 1996: 21. The four popular catastrophe loss models have been developed by Equcat, TPF\&C. RMS and CatMap. 
The specter of the enormous costs associated with such aptly named "shock" or catastrophe losses has justifiably alarmed insurance and reinsurance executives in the U.S. as they realize that their exposure to property catastrophe loss is substantially higher than expected and, in many cases, significantly larger than they are willing to retain. Shock losses are not limited to property exposures. Already the estimated cost of future asbestos and environmental claims in the U.S. is in excess of $\$ 57$ billion. ${ }^{4}$ With other mass torts on the horizon, the long tail on such claims, still in their infancy, will likely end up costing tens of billions of dollars. This realization, coupled with the fact that current total insurance and reinsurance capacity in the United States is $\$ 200$ to $\$ 225$ billion, with less than $\$ 20$ billion of reinsurance capacity for property catastrophe risks has precipitated a surge of insurer interest in the capital markets which have about $\$ 17$ trillion in investable wealth that may fluctuate on a daily basis by roughly $\$ 133$ million. ${ }^{5}$

Insurer interest in the capital markets presents reinsurers with a critical challenge: reinsurers must recognize that their own business viability in the future increasingly will depend on their ability to support their own customer franchise in funding the event risks of the future, whether by traditional methods or by accessing the capital markets. Although the current efforts of the capital markets in entering the insurance arena are in many regards exploratory in nature, the development of new insurance derivative and securitized products have the potential to usurp the role previously held by reinsurers. This dynamic has resulted in a subtle, yet palpable, tension between reinsurers and the capital markets.

\section{Capital responses to insurers needs}

When a huge catastrophic loss hits, whether as a result of a natural peril, casualty event or any other form of business liability, the risk that an insurer's capital will be reduced significantly translates into: (i) a decline in profits because revenue otherwise attributable to earnings is used to pay claims or other liabilities; (ii) a decline in underwriting capacity which occurs because the supply of capital is reduced; and (iii) a danger that reinsurance costs in response to catastrophic losses will rise more quickly than underlying insurance rates. The unexpected reduction in capital is what is referred to as "event" risk. Event risk can be further exacerbated by the risk that the value of unpaid policyholder claims will exceed available reinsurance recoverables, driving the insurer into insolvency. ${ }^{6}$ Thus, event risk borne by insurers and rising reinsurance costs are leading insurers to reexamine how they think about and manage risk, capital and corporate results.

In managing event risk, the need for adequate capital is crucial. In anticipation of a shortfall in the capital needed to respond to a catastrophic event, an insurer can obtain capital in two ways: either before a loss occurs (ex ante capital) or afterwards (ex post capital). ${ }^{7}$

${ }^{4}$ Eric Simpson, W. Dolson Smith and Cynthia S. Babbitt. "Insurers Chip Away at E\&A Liabilities”, Best's Review Property/Casualty Supplement, April 1996, pp. 39-40.

5 Donna Hill, The Convergence of The Financial and Insurance Markets (International Risk Management) 23. See also, Sean Mooney, "Capital Markets Developing Slowly As Insurance Supplement", National Underwriter, 2 Sept. 1996, p. 33.

6 Scott Harrington, Steven Mann and Greg Niehaus, "Insurer Capital Structure Decisions and the Viability of Insurance Derivatives”, Journal of Risk and Insurance, Vol. 62.3, , 1995, p. 486.

${ }^{7}$ Harrington pp. 486-487. 
Up until now, ex ante capital, being a function of equity investment in insurance and reinsurance stocks, was thought to be an efficient and mutually effective solution for insurers and the capital markets. Yet, ex ante capital investments subject investors not only to all insurance risks, but also to all business risks of the corporate entity. Investors are also subject to double taxation: first, at the corporate level and second, on dividends at the personal level. In many cases, investors rates of return have not met their stated goals. This has resulted in tepid interest on the part of the investment community in insurer and reinsurer stocks when compared to the high interest shown in biotechnology and other high technology issues.

Moreover, ex ante capital has proven to be a poison apple for the insurance industry. Although the flow of ex ante capital into the insurance industry would seem to be a good sign, capital obtained this way actually has a negative effect on insurer profitability. This paradox occurs for two reasons. First, a steady flow of ex ante capital into the insurance sector creates an abundance of capacity which forces insurers to compete for business, driving rates down as well as earnings. Second, while an insurer with too much underutilized ex ante capital may be protected in case of spikes in losses due to event risk, unless that capital is intelligently deployed, the earnings potential of that company will be trapped. It is odd that today's soft market may be the result of this paradox.

In contrast, raising capital after the need arises is more attractive for insurers and investors. Several reasons account for this. First, ex post capital has none of the disadvantages of ex ante capital financing, e.g., there is no double taxation. Second, when the terms of the ex post capital commitment are negotiated and agreed on before the loss occurs, the commitments is not subject to various market inefficiencies that typically occur after a catastrophic event and the risk of default is substantially removed i.e., the danger that either investors will renege on their promise to supply funds or the insurer will renege on its promise to issue equity (because the value of the equity would most likely be depressed).

Reinsurance is a form of ex post capital as are derivatives and various securitized insurance products. Yet, however successful reinsurance is as a risk transfer mechanism, there are drawbacks when writing catastrophe exposed risks. Catastrophe exposures require a greater allocation of corporate capital than ever before, which can reduce the amount of capital remaining to support other less risky and potentially more profitable business. And when the next megacatastrophe occurs, the chance that the cost will be beyond the total present capacity of the insurance and reinsurance marketplace makes the insolvency risk uncomfortably high. A good measure of these problems could be mitigated by exchange-traded insurance derivatives, which are "marked to market" on a daily basis 8 in exchanges where traders are subject to margin calls or performance bonds, ${ }^{9}$ or securitized instruments.

${ }^{8}$ The adoption of FASB \#115 required the marked to market approach for fixed income securities. For a discussion of the marked to market concept, see Robert Hoyt \& Reesa Williams, "The Effectiveness of Catastrophe Futures as a Hedging Mechanism for Insurers", Journal of Insurance Regulation, Fall 1995, p. 32.

${ }^{9}$ Harrington p. 489. 
As insurers begin to actively investigate the economic feasibility of the capital market alternatives for shifting risk to deeper pockets of wealth, reinsurers must not be complacent. Apprehension about the direction of the future can cost reinsurers their customer base, losing out to either the capital markets directly or those reinsurers that are learning about the risk management techniques used by the financial markets.

\section{Seizing the opportunities}

Reinsurers that explore the new risk shifting capital market alternatives that can increase the capacity available to insurers will be better equipped to capitalize on the opportunities that the capital markets will inevitably bring to the insurance industry. Traditionally, most managers of insurance and reinsurance companies have depended upon the Law of Large Numbers to guide their decisions about how to manage the insurance exposure they are willing to assume. Reinsurance from this perspective is seen simply as another tool which applies the Law of Large Numbers to create a risk spreading mechanism. Yet, the form of event risk known as catastrophe risk, characterized by high severity and low frequency, can disrupt the risk spreading mechanism by breaking down the independence of the exposure units that are, in essence, being pooled. ${ }^{10}$ The emergence of finite reinsurance forced traditionalists to broaden their views as reinsurance became accepted as a financing arrangement, extending for insurers the period of time for paying back reinsurers in respect of the losses the insurer has sustained. Now, with the capital markets finding new ways that event risk can support the creation of products that shift the risk outside the insurance industry, reinsurers are being dared yet again to move the goalposts that define their products and services.

This situation is in many respects analogous to the set of circumstances that existed in the late 1970's in the United States when U.S. monetary policies resulted in great volatility in interest rates which in turn created excessive risks for the holders of U.S. Treasury Bonds. Accompanying the great fluctuations in interest rates was a sharp increase in the insurance of government and private debt. These two elements led to the development of U.S. Bond Futures, a derivative product that shifted interest rate risk to the capital markets and thus provided investors in primary government securities with a hedge to limit their losses in these instruments. After a slow start, these new products exploded, as is shown by the 1995 trading volume which is in excess of a stunning $\$ 7$ trillion. ${ }^{11}$ Moreover, the notional amount of the global derivatives market as of August 1994 was in excess of $\$ 35$ trillion. ${ }^{12}$

\section{Obstacles to investor interest}

To date, investors continue to be skittish about the new capital market products. This lukewarm reception has beleaguered the financial institutions, reinsurers and reinsurance intermediaries engineering these new vehicles: tremendous energy and effort has been diverted from other more sure-fire money making opportunities without significant results. Several factors account for the tentative interest of investors.

${ }^{10}$ Robert Hoyt \& Reesa Williams, "The Effectiveness of Catastrophe Futures as a Hedging Mechanism for Insurers", Journal of Insurance Regulation, Fall 1995, p. 62.

${ }^{11}$ Henry Hu, "Hedging Expectations: 'Derivative Reality' and the Law and Finance of the Corporate Objective", Texas Law Review, Vol. 5 1995, p. 988.

${ }_{12} \mathrm{Hu}$ p. 288. 
Illiquidity. The value of the insurance derivative call spread option contracts traded on the Chicago Board Of Trade (CBOT) depends on the aggregate catastrophe losses determined by the Property Claim Services (PCS) Index and is not influenced by market demand. The price of premium paid for these contracts is, however, a function of the marketplace. Because of their limited risk and limited reward characteristics, these call spreads are currently used principally as hedging vehicles and nor for speculative trading. Yet, demand even for hedging purposes remains low as evidenced by the small orders and dearth of buyers. In fact, research shows that exchange-traded insurance derivatives have a market penetration of under $1 \%$ if these instruments were being employed to hedge all premiums in respect of catastrophe lines. ${ }^{13}$ This creates a problem for investors that may want to liquidate their positions quickly. Taken together, the lack of a strong buy side and an illiquid market make potential investors in this market leery of entry.

Need for education. Although corporate investors may be comfortable with hedging monetary risks and speculating in asset-backed securities, the catastrophe component of event risk frightens them. The perception that insurance risks are difficult to fully understand and price for was in all likelihood advanced by the problems at Lloyds. Even exceptionally high rates of return have not been enough to compensate investors for assuming catastrophe risk. ${ }^{14}$ Whether this is rational or not, investors' lack of understanding of catastrophe risk will constrain the acceptance and growth of these capital market products. There also is a need for insurers to improve their learning curve regarding the hedging and arbitrage techniques so familiar to the capital markets.

Price determination. Investors generally want some assurance that the price of insurance risk is attractive and competitive. Yet, the lack of any non-insurance standard to compare these products against makes it very difficult for investors to independently verify price. Also, many investors are unsettled by the fact that their returns are based on circumstances over which they have no control.

Regulatory and accounting issues. Another perceived danger on the part of investors is the fact that the insurance industry is state regulated, which imposes various restrictions on the use of derivative and securitized vehicles. About half of the states in the United States have regulations that allow insurers to use futures and options on futures for hedging their general assets. However, the definition of what constitutes a "hedge" versus a "speculative" trade is subjective and open to interpretation. Only New York, Illinois and California specifically allow trading in exchange-traded insurance derivative contracts. Yet the scope of authorized activity and the limitations on the amount that may be invested under these laws need to be updated and clarified. The failure of the states to act on this is a major obstacle for insurers. ${ }^{15}$ Stronger efforts by insurer lobbying groups urging legislators and insurance regulators to issue new or amended laws would better serve the interests of both investors and insurers. Another regulatory roadblock affects the use of surplus notes. Because surplus notes are subordinated debt, regulatory approval is generally required for their

\footnotetext{
13 Hoyt p. 44.

14 This is the conclusion that can be drawn from the failure of the USAA offering.

15 "Futures and Options Trading For Insurance Companies: The Regulatory Environment", White Paper Series 4 (Chicago: Chicago Mercantile Exchange, 1991).
} 
issuance and the repayment of principal and interest at maturity. ${ }^{16} \mathrm{As}$ respects statutory and GAAP accounting issues, there is very little specific guidance because these products are so new and unique. For example, even though the National Association of Insurance Commissioners has issued guidelines that require both hedging and non-hedging income be reported in the Annual Statement as "aggregate write-in for miscellaneous income", the guidelines only address where to record these items on the annual statement, and not the timing or the determination of the actual amounts to be recorded..$^{17}$ Thus, accounting issues in this area are generally resolved on a case by case basis by the individual company.

\section{Capturing investors interest}

A number of interesting observations have been made about catastrophe risk by reinsurance intermediaries and investment banks for marketing purposes to investors. ${ }^{18}$

Assetization of catastrophe risk. The first is that catastrophe risk is an asset class, similar to mortgages and car loans, which can be transformed into securities that can be traded in the capital markets. The assetization of catastrophe risk will largely benefit institutional investors by giving them a broader array of investment options to diversify the holdings in their portfolios. The resulting diversity lowers the volatility in an investor's portfolio because catastrophe risk is uncorrelated with economic or political movements that affect most monetary risks, i.e., interest rate, exchange rate and currency risks. Economic theorists posit that the uncorrelated nature of catastrophe risks should be reflected in lower "fair" rate of return requirements to investors. In spite of this, research has shown that catastrophe risk investments on average can generate returns substantially in excess of this rate. Thus, assetization of catastrophe risk can improve investors' reward-to-risk ratio goals. ${ }^{19}$

Disaggregation of risk. Another approach taken by the so-called financial engineers of these products is to segment out individual catastrophe exposed risks from an insurer's or reinsurer's entire underwriting portfolio. The "disaggregation of risk" approach is believed to promote efficiency by offering investors a better opportunity to understand the risk profile of specific exposures, rather than the aggregated exposures inherent in an insurer or reinsurer's entire book of business. With this method, it is possible that investors may not need as high a margin as compensation for the uncertainty about the catastrophe exposure. This is because risk analysis can be more focused on the specific exposures at risk in an event loss.

\section{What's out there}

The capital market vehicles to date are clearly in an embryonic stage. They are being engineered to allow insurers or reinsurers to shift - rather than spread - some or all of the risks they do not want. The present forms of the new insurance derivatives and securitized

16 "Surplus Notes: A Viable Financing Vehicle", Best Week: Property/Casualty Supplement, 11 March 1996, p. 1.

17 Hoyt, p. 49.

18 The Emerging Asset Class: Insurance Risk: Guy Carpenter's Review of Catastrophe Exposures and the Capital Markets, July 1995 and "Insurance Derivatives and Securitization: New Hedging Perspectives for the US Catastrophe Insurance Market?" Sigma, vol. 5, 1996.

${ }^{19}$ The Emerging Asset Class: Insurance Risk: Guy Carpenter's Review of Catastrophe Exposures and the Capital Markets, July 1995. 
insurance arrangements that in essence convert insurance premiums into a form of fixed income securities should be regarded as experimental in nature.

PCS Options on the CBOT. The PCS Option call spreads offered by the Chicago Board of Trade allow an insurer or reinsurer to offset and limit its losses in excess of its projected catastrophe losses, in essence creating a layer of synthetic reinsurance.

In contrast to traditional reinsurance, which is a tailored product, the PCS Options are largely standardized. The CBOT, which withdrew its earlier loss ratio index based on ISO data, introduced in 1995 a new standardized index based upon an estimate of aggregate catastrophe losses in the U.S. as measured by PCS. PCS furnishes the CBOT nine indices daily, based on its own industry accepted estimates of insured catastrophe losses in the covered geographic areas. An insurer or reinsurer can determine what catastrophe loss exposure it wants to hedge or trade by selecting the index and the loss period to be covered that is appropriate for the geographic area (a September Eastern contract hedges against hurricane exposure for the third quarter loss period). Each PCS loss index represents the sum of then-current PCS estimates for insured catastrophic losses for the geographic area and loss period covered divided by $\$ 100$ million. ${ }^{20}$

These call spreads function in much the same manner as a layer of aggregate excess of loss reinsurance that is bought for catastrophe protection. Buyers of a call spread create a layer of protection between two "strike" or exercise prices whose value is determined at the option's expiration based on the aggregate catastrophe losses applicable to the parameters of the options contract. Insurers may purchase these options to limit their retention levels to acceptable amounts with respect to a specific catastrophic loss exposure. They may also purchase them as an alternative to reinstating coverage under a traditional catastrophe program if the cost differential between the call spread and the reinsurance protection favors purchase of the options. These options may be purchased before, during or even after a specific event, recognizing that differences in timing will affect the value of the contracts. Recently, the trading volume of these options dramatically increased just before Hurricane Fran was expected to make landfall dramatizing how these call spreads can quickly supplement existing reinsurance protection. ${ }^{21}$

20 The loss estimates may be re-estimated by PCS, who advises Chicago Board of Trade. PCS announces the release time of an estimate or re-estimate they will make for an industry loss from a specified catastrophe. The nine geographic indices are: National, covering all states; Regional, comprised of Eastern, Northwestern, Southeastern, Midwestern and Western, and three single state indices: California, Florida and Texas. Each index point equals $\$ 200 \mathrm{cash}$ value. The two separate contract types available are denominated: (i) Small Cap reflects an aggregate industry catastrophic loss during a loss period of $\$ 0$ to $\$ 20$ Billion; and (ii) Large Cap, reflecting a $\$ 20$ Billion to $\$ 50$ billion aggregate industry loss. For seven of the geographic indices, the loss period of coverage is a calendar quarter which is reflected in the name of the contracts purchased, e.g., a March contract is the contract name for the First Quarter Loss Period Contract. The remaining two indices, California and Western, track annual loss periods. Additionally, the development period is known as the settlement date, e.g. the development period of April 1 to September 30 has a settlement date of September 30.

Chicago Board of Trade. PCS Catastrophe Insurance Options: A User's Guide, Chicago City of Chicago Press, 1995, pp. 3-6.

21 Chicago Board of Trade, Catastrophe Derivatives Year to Date List of Trades Chicago City of Chicago Press, 1995. 
One obstacle that constrains wide-spread insurer acceptance of this product is limited understanding of how to effectively develop a good hedging strategy. To do this, an insurer must analyze the correlated risk present between its portfolio and the components of the PCS index, which means that insurers need to determine (i) whether they have significant exposure in the lines of business that are included in the PCS index; and (ii) whether their company-specific catastrophe loss estimates are highly correlated with those of the industry. This analysis should help to mitigate any basis risk, namely the risk that the value of the option contract does not move in line with the insurer's underlying exposures. Correlated risk is somewhat less important for reinsurers because they insure a company's entire portfolio of property risks.

Contingent surplus notes. Surplus notes allow insurers to borrow money from the capital markets to support business growth or to provide extra protection to the health of an ailing company. They are attractive to insurers because the sale of surplus notes increases an insurer's assets, with no corresponding increase in liabilities for statutory accounting purposes. Contingent surplus notes offer the same accounting benefits and are intended to provide capital to an insurer in the event of catastrophic losses. These arrangements also do not carry basis risk. From an investors perspective, there is an element of credit risk in that the insurer could default on its payment obligations, as a result of regulatory fiat or bankruptcy. A large measure of the success of the two successfully completed contingent surplus note offerings discussed below was due to the fact that the catastrophe coverage was embedded in a broadly framed "any purpose" contingency.

In February 1995, Nationwide, an Ohio mutual insurer writing a significant homeowners book, made use of surplus notes as part of the corporation's strategic protection against catastrophe loss. They issued $\$ 400$ million of contingent surplus notes to institutional investors which could be accessed for any business reason, thus not specifically linking them to the occurrence of a catastrophic event. A Nationwide Contingent Surplus Note (CSN) Trust was created which invested the proceeds of the issue in 10 year U.S. Treasuries. Investors are to receive 2.2 percentage points above the 10 year U.S. Treasuries until such time as Nationwide elects to issue the surplus notes, which it may do at any point during a 10 year period by liquidating the Treasuries. The notes will mature in thirty years, 2025 , if issued, and will carry a $9.922 \%$ coupon. At maturity, the CSN Trust must redeem the notes. Insurance Department approval, however, is required before repayment to investors is permitted. The annual cost to Nationwide for maintaining this commitment for future capital is the difference between the coupon on the notes and the yield on the 10 year Treasuries. ${ }^{22}$

In April 1996, Arkwright Mutual Insurance Company, a Massachusetts property insurer underwriting highly protected commercial and industrial risks, offered investors a contingent surplus notes opportunity that had more flexibility than the Nationwide deal. Like Nationwide, Arkwright's notes are designed to make capital available when surplus is impacted as a result of catastrophic losses - but there is no qualification in the offering that restricts Arkwright to the occurrence of catastrophe loss as the triggering contingency. A CSN Trust was set up to issue $\$ 100$ million of 30 year U.S. Treasuries. Investors receive 2.5 percentage points above the 30 year Treasuries. If at anytime in the next 20 years,

22 "Surplus Notes: A Viable Financing Vehicle", Best Week: Property/Casualty Supplement, 11 March 1996, p. 11. 
Arkwright needs capital, it can issue up to $\$ 100$ million of surplus notes to the Trust in exchange for an equivalent amount in Treasuries, which could then be liquidated to pay claims. The principal and interest on the contingent surplus notes would be paid by Arkwright to the Trust. One difference between the Arkwright and Nationwide CSNTrust is that Arkwright has a revolving surplus facility, allowing it to restore the Treasuries to the Trust if the surplus is no longer needed. In the Nationwide deal, once Nationwide substitutes the Treasuries for surplus notes they are responsible for the coupon payments. Unlike the Nationwide deal, Arkwright can substitute the 30 year notes for surplus notes any time in a 20 year period instead of a 10 year period. ${ }^{23}$

Act of God Bonds. The USAA, a Texas underwriter of auto liability and homeowners policies, Act of God Bonds further expanded the contingent surplus notes vehicle, but more closely resembled reinsurance. In this capital market transaction, catastrophe loss was clearly the triggering event, which may have contributed to its short life. The financial institution underwriting the offering withdrew it without comment. This deal was an attempt to sell $\$ 500$ million in so-called "disaster bonds." A Cayman Island Special Purpose Reinsurance Company (SPRC) was established and capitalized at $\$ 125,000$. The sale of the bonds through the SPRC would allow USAA to cover $95 \%$ of its insured losses in excess of $\$ 1$ billion from a single hurricane in one year. Both interest and principal on the notes would be subordinated to the SPRC's obligations to USAA, in effect providing the SPRC with the surplus to pay the claims of USAA. Investors were to receive a return of about $15 \%$, substantially higher than investors received in the Nationwide and Arkwright deals, but they had to absorb the risk of losing their principal as well as their interest if the loss trigger occurred. Most investment grade corporate bonds return very small premiums over Treasuries. This should have made the $15 \%$ return highly attractive. However, investors are not accustomed to analyzing loss from natural catastrophes, which was described by one insurance analyst as a "crapshoot... you just cross your fingers and watch the Weather Channel." 24

CATEX. CATEX is not a capital market financing vehicle but, if successful, may have the potential to provide insurers and reinsurers with avenues to access capital. This facility, which opened in October 1, 1996, is a nationwide computer based trading exchange that will facilitate swaps of catastrophe exposures between insurers, reinsurers or self-insurers, who must register with the New York Insurance Department. Bidders for different deals will be able to pursue trades for different regions, peril groupings, contract types, lines of business and insurance products. Pricing the trade will ultimately be subject to the value each party places on the "relativity" of the portfolios being swapped. The relativities will reflect the proportional relationship between different risks, based on perils written, geographic distribution and line of business distribution. Each portfolio will be assigned its own relativity. Portfolios are to be swapped in standard trading blocks of $\$ 1,000,000$ of insured property exposure. The size of the aggregate swap will not be regulated. Trading rules call for a $20 \%$ co-participation by each party to discourage poor claims handling on claims being swapped. For statutory accounting purposes, all CATEX exchange contracts will be treated as reinsurance. ${ }^{25}$

${ }^{23}$ Insurance Finance \& Investment, New York: Institutional Investor, Inc., 6 May 1996, p. 12.

${ }^{24}$ BLOOMBERG BUSINESS NEWS, 19 August 1996, quoting Ira Zuckerman, an insurance Analyst at Nutmeg Securities. See also "A Capital Idea", Reactions, 16 January 1996, p. 16.

25 Insurance Finance \& Investment, New York: Institutional Investor, Inc., 8 April 1996, pp. 1-13. 
California Earthquake Authority. The California Earthquake Authority (CEA) is a legislative and regulatory program designed to provide earthquake coverage to California residents. The total capacity of the program is $\$ 10.5$ billion. It was originally intended that the capital markets would provide $\$ 1.5$ billion of capacity excess of $\$ 7$ billion, which would be accomplished by the sale of Act of God bonds in 3 series, although no final structure has initially been agreed. ${ }^{26}$ In a surprising turn of events in mid-November, Berkshire Hathaway, Warren Buffet's Omaha based firm, reached agreement to reinsure the entire capital markets portion of the CEA for a 4 year premium equal to $\$ 590$ million. ${ }^{27}$ It is not known at present whether Berkshire Hathaway will retain this exposure net or explore possible capital market involvement itself.

\section{What's a head}

Predicting the future in the world of insurance and finance carries its own risks. Inaccurate predictions often appear foolish in hindsight, but the failure to look ahead can be fatal. ${ }^{28}$ To be a market leader going forward, reinsurers must align their interests with those of their customers, or the capital markets will do so. Reinsurers need to understand not only the capacity requirements of their customers, but also the full spectrum of business risks their customers and they face. This may mean that the traditional process of risk analysis will need to expand beyond familiar loss and rating models, and selecting business opportunities based on balance sheet constraints. Reinsurers will become risk intermediaries to the capital markets as they better understand all the risks involved in a business opportunity, passing all or some of the event risks assumed to the capital markets, rather than absorbing it themselves.

It is inevitable that the capital markets will continue to invent new improved forms of the risk shifting products discussed above, which will be widely marketed and often copied. The establishment in greater numbers of financial laboratories within insurance and reinsurance companies should also occur. New products can then be designed, but more importantly applied in practice. The much touted convergence of the financial and insurance markets may ultimately materialize in the form of business conglomerates that offer the public full risk management services at prices reflecting the efficiencies obtained through the capital markets.

26 John P. Drennan, "The California Earthquake Authority - A Possible Solution to the Risk of Earthquake Insurance”, Journal of Reinsurance, Spring 1996, pp. 1-19.

${ }^{27}$ Bloomberg Business News, 18 Nov. 1996. p. 216

27 Victor Navasky, "Tomorrow Never Knows", New York Times Magazine, 29 September 1996, 
The number of catastrophes has fallen since the late seventies. .

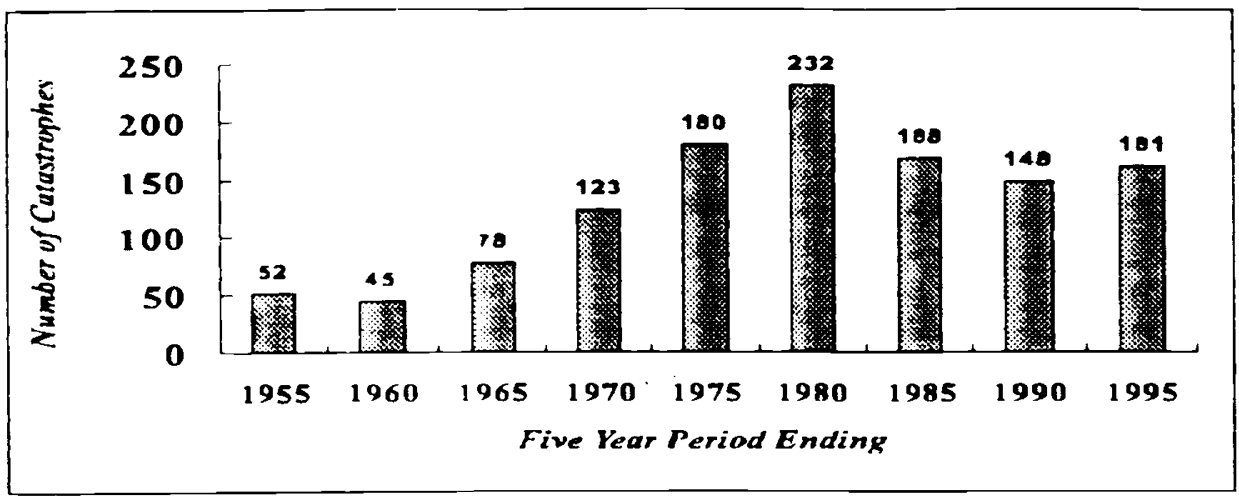

... but the average loss per catastrophe has soared since 1980

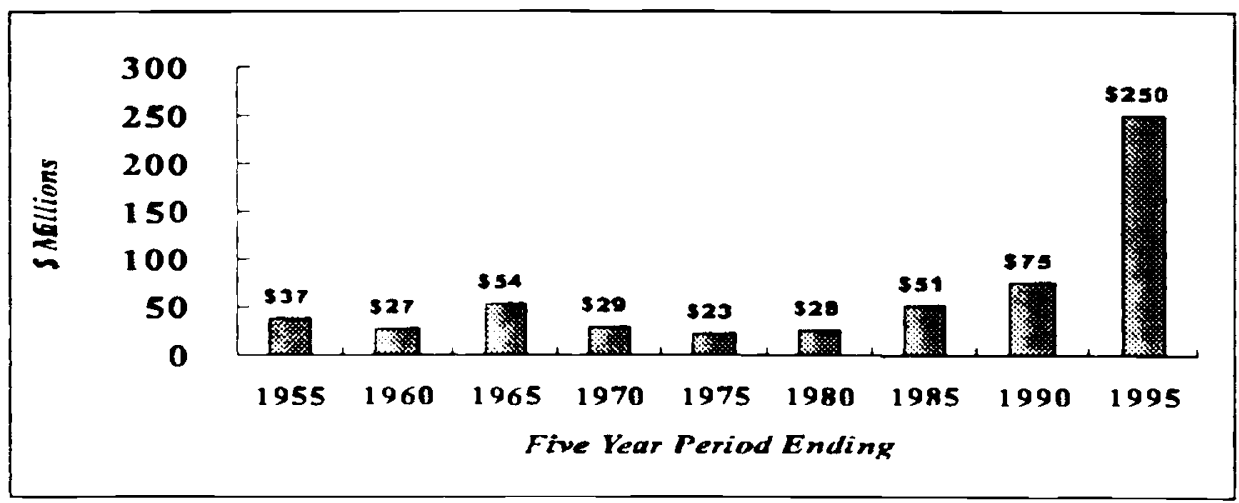

Consequently, total catastrophe losses have skyrocketed

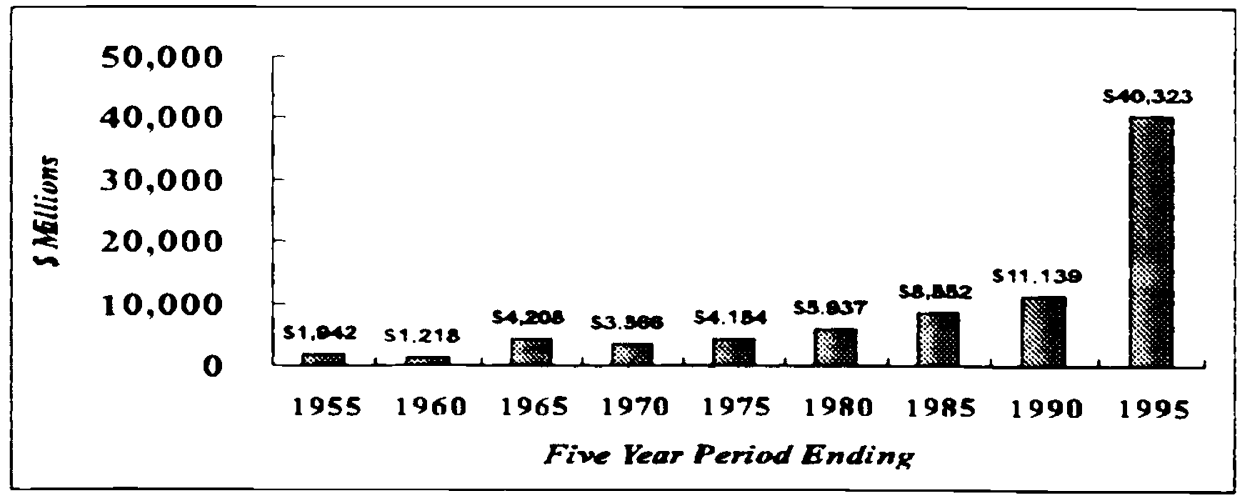




\section{REFERENCES}

BORDEN, Sara and SARKAR, Asam, "Securitizing Property Catastrophe Risk", Current Issues in Economics and Finance, August 1996, pp. 1-6.

"A Capital Idea", Reactions, 16 January 1996.

Chicago Board of Trade, PCS Catastrophe Insurance Options: A User's Guide, Chicago: City of Chicago Press, 1995.

DRENNAN, John P., "The California Earthquake Authority - A Possible Solution to the Risk of Earthquake Insurance", Journal of Reinsurance, Spring 1996, pp. 1-19.

"Futures and Options Trading for Insurance Companies: The Regulatory Environment", White Paper Series 4, Chicago: Chicago Mercantile Exchange, 1991.

HARRINGTON, Scott, MANN, Steven and NIEHAUS, Greg, "Insurer Capital Structure Decisions and the Viability of Insurance Derivativcs", Journal of Risk and Insurance, Vol. 62.3, 1995, pp. 482-508.

HILL, Donna, The Convergence of the Financial and Insurance Markets, International Risk Management, p. 23.

HOYT, Robert and REESA, Williams, "The Effectiveness of Catastrophe Futures as a Hedging Mechanism for Insurers", Journal of Insurance Regulation, Fall 1995.

HU, Henry, "Hedging Expectations: 'Derivative Reality' and the Law and Finance of the Corporate Objective", Texas Law Review, April 1995.

"Insurance Derivatives and Securitization": New Hedging Perspectives for the US Catastrophe Insurance Market?" Sigma, vol. 5, 1996.

Insurance Finance \& Investment, New York: Institutional Investor, Inc., 28 April 1996.

Insurance Finance \& Investment, New York: Institutional Investor, Inc., 6 May 1996.

LITZENBERGER, Robert H., BEAGLEHOLE, David R., REYNOLDS, Craig E., "Assessing Catastrophe Reinsurance-Linked Securities as a New Asset Class" Fixed Income Research, July 1996, p. 26.

MICHIE, R.C., "Development of Stock Markets", In The New Palgrave Dictionary of Money and Finance, vol. 1 Ed. Peter Newman et al, New York, Stockton Press, 1992, 3 vols.

MOONEY, Sean, "Capital Markets Developing Slowly As Insurance Supplement", National Underwriter, 2 Sept. 1996, p. 33.

MOONEY, Sean, "The Life and Death of Probable Maximum Loss", National Underwriter, 30 Sept. 1996, p. 21.

NAVASKY, Victor, “Tomorrow Never Knows”, New York Times Magazine, 29 September 1996.

SIMPSON, Eric, SMITH, W. Dolson and BABBITT, Cynthis S., "Insurers Chip Away at E\&A Liabilities", Best's Review: Property/Casualty Supplement, April 1996, pp.39-40.

"Surplus Notes: A Viable Financing Vehicle", Best Week Property/Casualty Supplement, 11 March 1996.

The Emerging Asset Class: Insurance Risk: Guy Carpenter's Review of Catastrophe Exposures and the Capital Markets, July 1995. 